\title{
Design and Performance of Small-scale Downdraft Biomass Gasification: A Case Study of Rice Husks
}

\author{
Ozkar F. Homzah ${ }^{1 *}$, Rachmat D Sampurno ${ }^{1}$, A Junaidi ${ }^{1}$, Dodi Tafrant ${ }^{1}$ \\ ${ }^{I}$ Department of Mechanical Engineering, Politeknik Negeri Sriwijaya, Palembang, Indonesia \\ *Corresponding author. Email: ozkarhomzah@polsri.ac.id
}

\begin{abstract}
Energy consumption and environmental pollutants have to become present issues. So, the reduced of energy fossil in the community is to overcome the highly prices of oil and gas. Therefore, an alternative energy innovation from biomass is needed. Gasification is to energy produces from solid material to convert into gases such as sawdust, leaves, rice husks and more gases. In this study, we made a small-scale design of biomass gasification. It will give more several advantages such as simple design, especially for rural area. In this research, we used methods consists of five stages. First is literature study; secondly to design and material process; thirdly is manufacturing and assembly; next stages is measurement and data collection; and the last stages is testing, which is evaluating the performance of gasification as possible modifying tools if needed. In this design, we used a fan-blower to supply fresh air as limited oxygen into the fuel column. The results of test, we obtained an average boiling time, the pot stove of 60 minutes which the temperature rises from $47.24^{\circ} \mathrm{C}$ to $66^{\circ} \mathrm{C}$. It showed the temperature pot stove have to highest reached to $79.5^{\circ} \mathrm{C}$ as the temperature available to water boiling. The performance test given the results as the hot start as the flame-fire temperature on top the stove. We obtained the highest temperature is to $146^{\circ} \mathrm{C}$ and the average temperature is reached to $104.9^{\circ} \mathrm{C}$. Based on that we estimated energy is to $5.314 \mathrm{~kJ} / \mathrm{hr}$, is required cooking for one family in Indonesia, the coned downdraft gasification was design and assembly; the total height and diameter of $0.752 \mathrm{~m}$ and of $0.158 \mathrm{~m}$. We found the thermal temperature reaches during the operation time varying between $45.8 \%$ - $64.4 \%$ it's lowest to the highest value test using thermocouple data. As a conclusion of this study, we obtained the temperature of pot-stove is slowly reaches from 59.5\% to $71.6 \%$ of boiling water.
\end{abstract}

Keywords: Gasification, Downdraft, Rice Husks, Small-Stove, Performance

\section{INTRODUCTION}

Energy consumption and environmental pollutants have to become present issues. So, the reduced of energy fossil in the community is to overcome the highly prices of oil and gas. Therefore, an alternative energy innovation from biomass is needed. As an alternative solution [1] showed that biomass is a complex organic compound consisting of carbohydrates, fats, protein and a few other minerals such as sodium, phosphorus, calcium and iron. In this case study, one of the processes that can convert biomass into energy is namely the gasification system.

Gasification is to energy produces from solid material to convert into gases such as sawdust, leaves, rice husks and more gases. According to [2] they fund the use of rice husks as an alternative energy using a gasification stove can be more effective and efficient, also they $[3,4,5,6,7]$ were deeply developed on biomass gasification stove technology. The other studies were [4] showed the performance of a continuous downdraft gasification furnace for rice husk fuel, where the gasification air flows in the same direction as the methane gas produced and the fuel is fed continuously during the methane gas formation process. His study showed the temperature result is $573^{\circ} \mathrm{C}$ and the ignition time is 6 minutes. It's slightly faster and the effective flame is taken by 62 minutes with the calorific value is 4369.21 $\mathrm{kJ}$.

The results study of [6] was designed a biomass stove with a batch system and have an efficiency of stove is $23.8 \%$, also this batch system of biomass stove is more efficient that the previous stove design. In 2019 [7] obtained the optimization of gasification of oil palm empty fruit bunches using powder a type of gasifier cyclone. He obtained that the larger the particle size and the lower air-fuel ration can produce the optimum 
temperature in the gasification process using a cyclone type of gasifier.

\subsection{Related Work}

According to the generation type of studies, we divided the existed work into two stages:

\subsubsection{Gasification theory}

The gasification process is a chemical process that converts biomass into gas fuel [8]. The gas produced is called as the Syngas in the form of $\mathrm{CO}, \mathrm{CO}_{2}, \mathrm{H}_{2}, \mathrm{CH}_{4}$ and $\mathrm{H}_{2} \mathrm{O}$ [9], also the gasifying form can be Oxygen, air and steam [10].

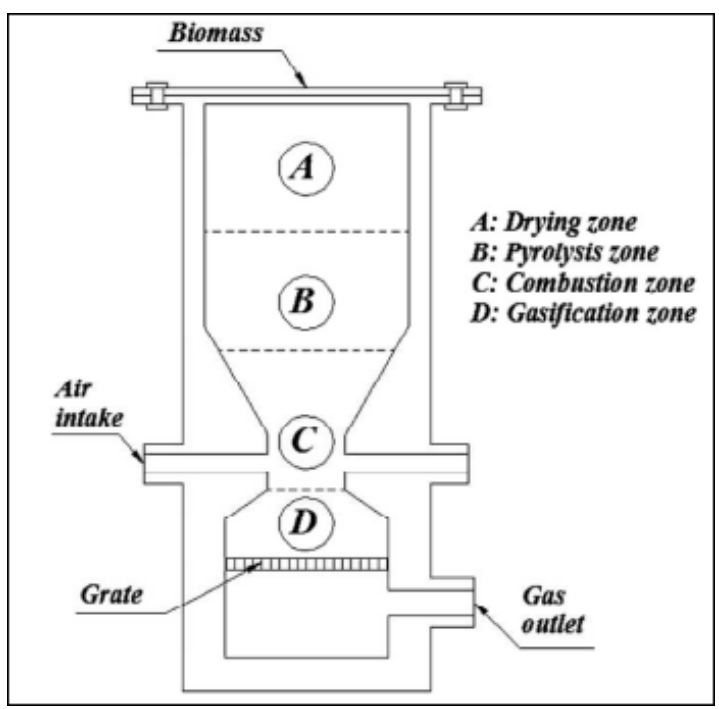

Figure 1. The downdraft gasifier furnace design [11]

Fig 1 illustrates the type of Throatless open top downdraft gasifier shows the high flexibility and efficiency in operating with solid fuels high during the operation process air and biomass pass through four zones inside the furnace such as drying, pyrolysis, reduction and oxidation.

\subsubsection{Gasifier furnace Performance}

The combustion zone is an Oxidation process is formed as the rate of oxygen level. The reaction with this form is highly exothermic and results is a sharp rise in temperature reached from $700^{\circ} \mathrm{C}$ to $1500^{\circ} \mathrm{C}$. According to [12] showed the combustion zone serves to convert and oxidize to almost all condensed products from the pyrolysis zone (see Figure 1) is operation present of the design gasifier as the combustion reaction.

$$
\begin{aligned}
& \mathrm{C}+\mathrm{O}_{2} \rightarrow \mathrm{CO}_{2} \\
& 2 \mathrm{H}_{2}+\mathrm{O}_{2} \rightarrow 2 \mathrm{H}_{2} \mathrm{O}
\end{aligned}
$$

For this reaction process showed the reduction zone involves as the series of endothermic reactions that was supported by heat produced from the combustion reaction. The products in the process are gas fuels such as $\mathrm{H}_{2} \mathrm{O}, \mathrm{CO}$ and $\mathrm{CH}_{4}$. Also the carbon dioxide $\left(\mathrm{CO}_{2}\right)$ and water vapor $\left(\mathrm{H}_{2} \mathrm{O}\right)$ are reduced to $\mathrm{CO}$

The carbon dioxide $\left(\mathrm{CO}_{2}\right)$ and water vapor $\left(\mathrm{H}_{2} \mathrm{O}\right)$ are reduced to $\mathrm{CO}, \mathrm{H}_{2}$ and $\mathrm{CH}_{4}$, in the following reactions are describes as the reaction zone.

$$
\begin{aligned}
& \mathrm{C}+\mathrm{CO}_{2} \rightarrow 2 \mathrm{CO} \\
& \mathrm{C}+\mathrm{H}_{2} \mathrm{O} \rightarrow \mathrm{CO}+\mathrm{H}_{2} \\
& \mathrm{CO}+\mathrm{H}_{2} \mathrm{O} \rightarrow \mathrm{CO}_{2}+\mathrm{H}_{2} \\
& \mathrm{C}+2 \mathrm{H}_{2} \rightarrow \mathrm{CH}_{4}
\end{aligned}
$$

\subsection{Our Contribution}

This paper presents some improvements based on the related our framework by Fajri Vidian et al [16]. The Models of CFD Simulation study showed that the increase of equivalence ratio tend to decrease of $\mathrm{CO}, \mathrm{H}_{2}$, $\mathrm{CH}_{4}$ and tar followed by increasing of temperature at the inside of the gasifier.

\section{METHOD AND MATERIALS}

\subsection{Methods}

In this research the methods that will be used include observations, study literature, design and material section, assembly process, collect the data and testing of the prototype also evaluating the performance of temperature reaches. The order of research can be explained by the flow chart in Fig 2. The main designed steps were as follows:

2.1.1. Energy needed (Q), According to [13] described more 12.7 million households are still dependent on traditional biomass fuels for cooking with the consequent health damages and costs in Indonesian women's time. The total energy consumption threshold at the level the extreme need is $580 \mathrm{kWh}$ [14].

2.1.2. According to [15] described the Fuel Consumption Rate (FCR) as the amount of heating value of rice husk is $3537 \mathrm{kcal} / \mathrm{kg}$ and high heating value is $4350 \mathrm{~kJ} / \mathrm{Nm}^{3}$ and $\mathrm{FCR}$ determined using Equation 7, $\eta$ taken as $17 \%$ as report by Ismail et al [17].

$$
\mathrm{FCR}=\frac{Q}{(H H V x \boldsymbol{\eta})}
$$

2.1.3. For time to consume rice husk $(\mathrm{T})$ is time to completely burn all rice husks in the furnace and 
it was calculated using Equation 8. However, depend on the volume of the furnace $\left(\mathrm{m}^{3}\right)$, the density of rice husk $\left(\rho_{\text {rh }}\right)$ and FCR.

$$
\mathrm{T}=\frac{\operatorname{\rho rh} x \boldsymbol{V r}}{\boldsymbol{F C R}}
$$

\subsection{Materials}

Our research was conducted in the design and testing the performance of a small-scale downdraft biomass gasification using Rice Husks is a solid fuel. This study, we make simulating the hot gases flow used the Autodesk to know the air inlet flow to combustion chamber. In the design we used insulation material to reduce heat loss and the material will give the effectiveness and availability. On this design, we used the stove from burning due to direct contact with the hot surface of the gasifier and the main body of cook-stove was shielded used galvanized mesh. For the inlet and outlet cylinder was made from galvanized sheet respectively (see table 1). The frame of char grate we used the handle for the burner assembly as body support and the lever are also made of galvanized material. For the air supply to the furnace, we used the $20 \mathrm{~W}, 220 \mathrm{~V}$ (AC) blower fan with the flow rate of 5.6 $\mathrm{m}^{3} / \mathrm{h}$. The last component is a switch to connect the electrical wiring for the fan and the thermocouple to regulate the amount of air delivered and air temperature during the performance test.

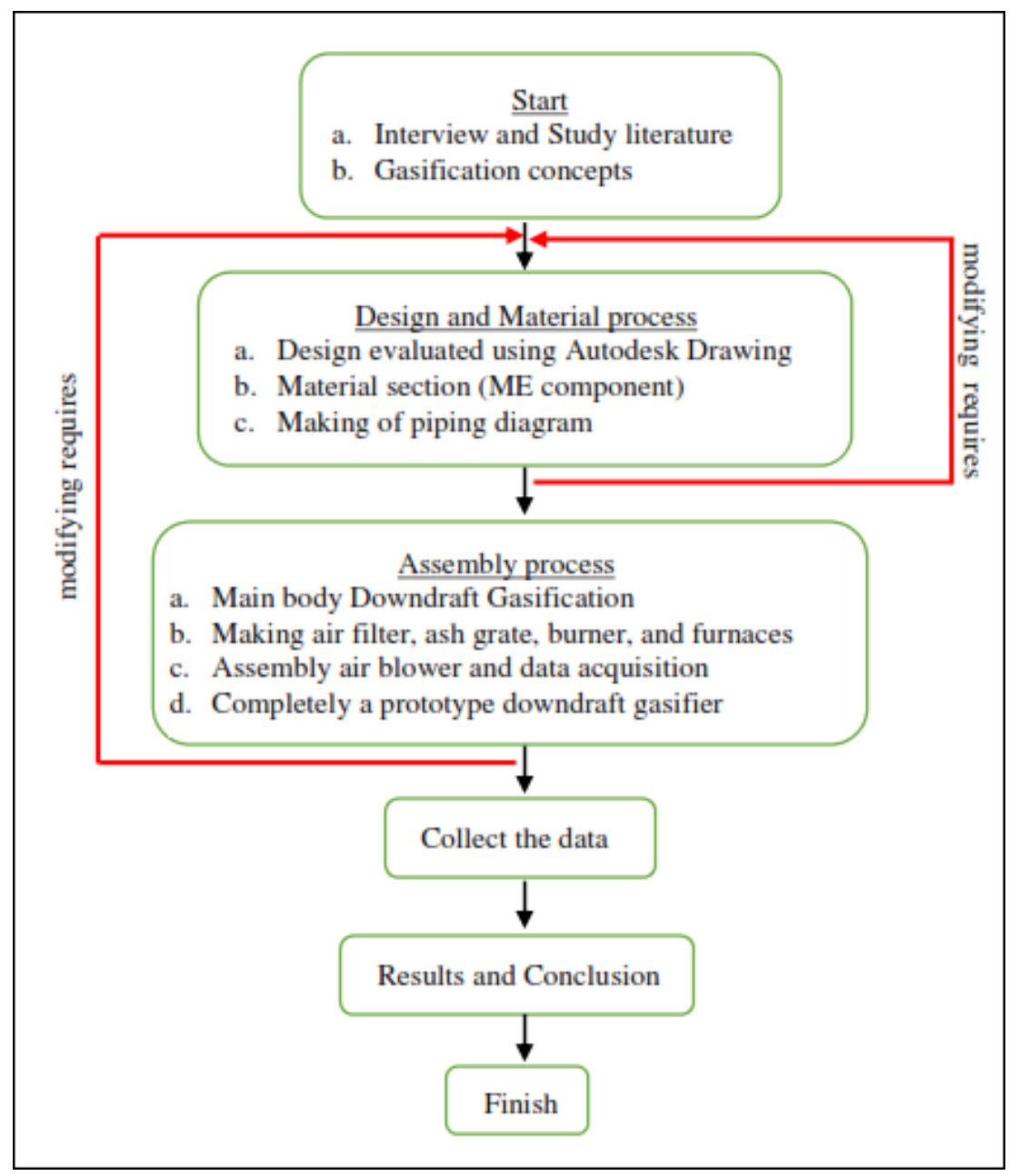

Figure 2. Design of Research flowchart

Table 1. The parameters design and the properties of the gasification

\begin{tabular}{|c|c|}
\hline Parameter & Specification \\
\hline The energy design $(\mathrm{kJ} / \mathrm{hr})$ & 5.314 \\
\hline FCR $(\mathrm{kg} / \mathrm{hr})$ & 1.250 \\
\hline Outlet diameter Furnace $(\mathrm{m})$ & 0.217 \\
\hline Inlet diameter Furnace $(\mathrm{m})$ & 0.158 \\
\hline
\end{tabular}




\begin{tabular}{|c|c|}
\hline Furnace height $(\mathrm{m})$ & 0.752 \\
\hline Cross section Area $\left(\mathrm{m}^{2}\right)$ & 0.009 \\
\hline Insulation type & Refractory cement SK-34 \\
\hline Inlet cylinder type & Galvanized steel sheet no.22 \\
\hline Outlet cylinder type & Galvanized iron sheet no.18 \\
\hline Blower fan type & $\mathrm{AC}, 20 \mathrm{~W} ; 220 \mathrm{~V}$ \\
\hline Thermocouple type & Type $\mathrm{j}\left(<760^{\circ} \mathrm{C}\right)$ \\
\hline
\end{tabular}

\section{RESULTS AND DISCUSSION}

The final result of this design is obtained for the configuration of the gasification furnace. We used a downdraft gasifier and biomass fuel from the rice husks.

\subsection{Assembly Process}

This research was conducted in a small-scale downdraft biomass gasification. The average energy required test was estimated $691.92 \mathrm{kCal} / \mathrm{hr}$. On this study, we made a small gasification furnace with inlet diameter and height was calculated to be $0.158 \mathrm{~m}$ and $0.752 \mathrm{~m}$ respectively with fuel consumption rate of $1.25 \mathrm{~kg} / \mathrm{hr}$. Table 1 . Illustrated the parameters design and the properties of the gasification.

\subsection{Operation Process}

During the gasification process, we used equation 1 to 6 present balanced chemical reaction equations during the gasification processes. Figure 3 is illustrated the unit design of gasification furnace, we used main configuration 1 to 7 presented as (1) blower-fan, (2) Hole-cover on top the furnace, (3) first burner, (4) Holecover on middle the stove, (5) stove, (6) air supply valve control, (7) pipeline gases product.

For first operation is the rice husk was ignited on first burner of furnace using pieces of paper or drying leaves. Due to the heat of the burning fuel layer at the bottom, the layer just upper the burning to release the pyrolysis gases. The gas burn using the air down from the side bottom of the furnace by the blower-fan.

Next, the burning zone have to continuously move downward and to utilise the available unburnt fuel. Primary air drawn from the bottom of the furnace passes through the bed of burning rice husk and carries the volatiles, leaving the charred husk.

For the resulting gas then passes through the char available in the bottom zone and is reduced to a lowenergy fuel gas and it rises pipeline gases to stove. We used the Holes introduced in the burner at the top of the stove during ignition help distributes the flame evenly all around the cooking pan.

For the performance test, the bottom layer contains charred husk; the intermediate layer is the flaming pyrolysis zone and the top layer contains unburnt fuel.
Figure 4 presents operation of the downdraft gasifier designed.

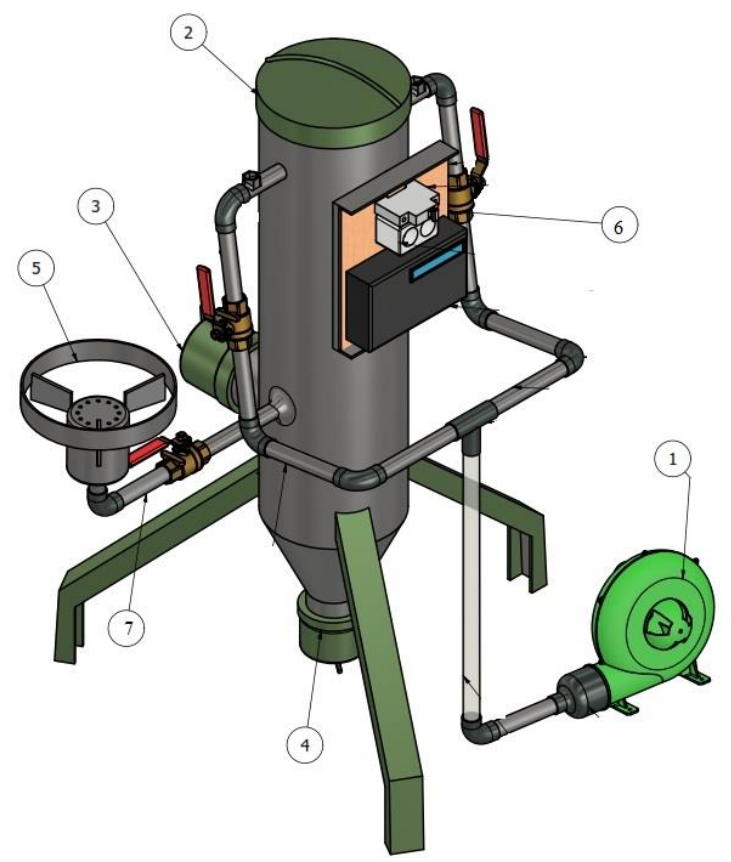

Figure 3. Completely design of gasification furnace

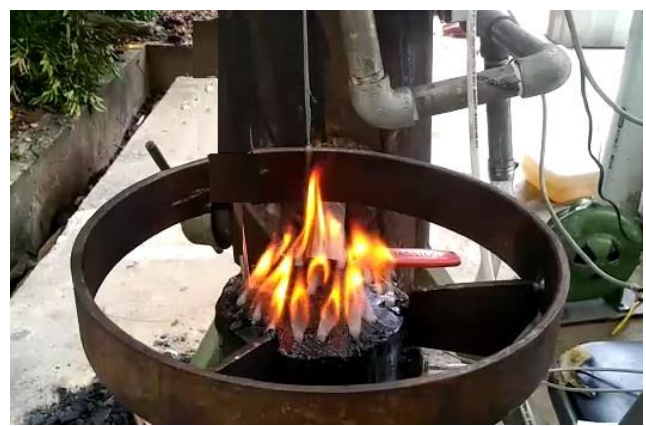

Figure 4. Operation of the gasifier

\subsection{The performance test}

On the design, we used assuming the developed rice husk gasifier is utilized three times a day in a case study. The average cooking power of this cook-stove was also established to be 1,589.04 Watt. Figure 5 illustrate the performance of temperature rises during the water 
boiling test likely hot start and pot stove. The boiling time of the stove is a measure of its cooking time. We used at ambient pressure of $101.33 \mathrm{kPa}$, than the test is taken to 5 hours operation and fuel consumption rate of $1.25 \mathrm{~kg} / \mathrm{hr}$. As results test, an average boiling time for improved pot stove of 60 minutes which the temperature rises from $47.24^{\circ} \mathrm{C}$ to $66^{\circ} \mathrm{C}$ also it showed for temperature pot stove have highest reached to $79.5^{\circ} \mathrm{C}$ it's show the temperature available to boiling the water. The performance parameter also shows that the Hot start as flame temperature on top the stove. We obtained the highest temperature is to $146^{\circ} \mathrm{C}$ and the average temperature is reached to $104.9^{\circ} \mathrm{C}$. Even though, in the gasifier design we not make the emission analysis of the developed small-scale downdraft gasifier. In future study, the findings of the design conform to previous findings stated that solid fuel cook-stoves without effective chimneys and adequate ventilation are unable to reduce indoor air pollution to levels set by Indonesian policy.

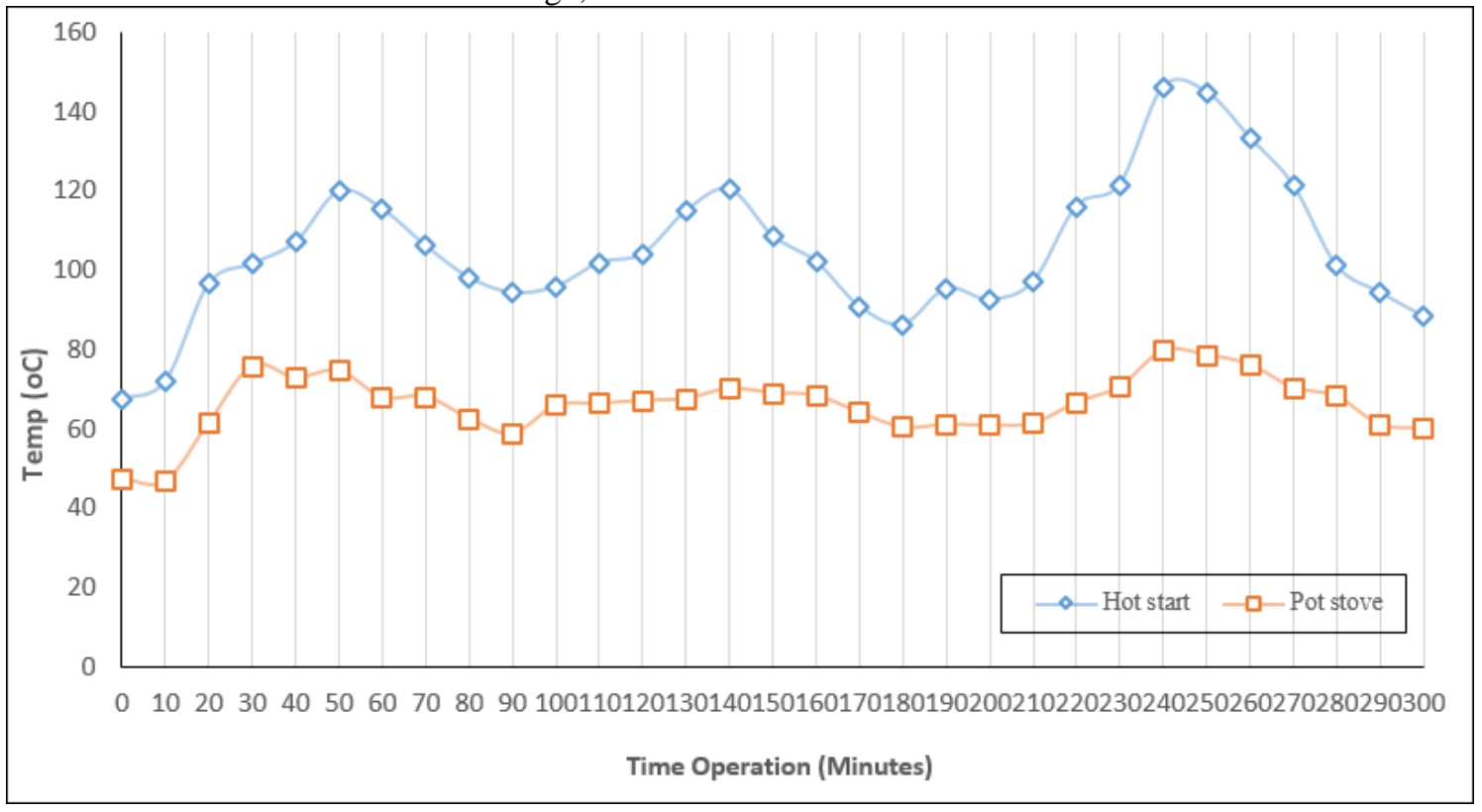

Figure 5 Performance test of Temperature rises

\section{CONCLUSION}

In this research; we have been design, assembly and thermal performance test for a small-scale downdraft biomass gasification. We used the estimated energy $(5.314 \mathrm{~kJ} / \mathrm{hr})$ for cooking required for a family in Indonesia. We made design and assembly with total height of $0.752 \mathrm{~m}$ and the diameter of $0.158 \mathrm{~m}$. As the results of the performance test showed the thermal temperature reaches during the operation time varying between $45.8 \%$ - $64.4 \%$ that the lowest to the highest value test using thermocouple data. As a conclusion of performance test, we found the temperature of pot-stove is slowly reaches from $59.5 \%$ to $71.6 \%$ of boiling water.

\section{ACKNOWLEDGMENT}

This work was financial supported by Politeknik Negeri Sriwijaya of PENELITIAN PENUGASAN INOVASI with a number of contract is 3629/PL.6.2.1/LT/2021 for a year founded.

\section{REFERENCES}

[1] Silalahi., 2000. Penelitian Pembuatan Briket Kayu dari Serbuk Gergajian Kayu. Bogor: Hasil Penelitian Industri DEFERINDAG.

[2] Isworo Pujotomo., 2017, Potensi Pemanfaatan Biomassa Sekam Padi Untuk Pembangkit Listrik Melalui Teknologi Gasifikasi. Jurnal Energi dan kelistrikan Vol. 9 No. 2, Juni - Desember 2017.

[3] G.N.A. Satria Prasetya D.Y., Made Sucipta., I Nyoman Suprapta Winaya., 2015. Perancangan 
Gasifikasi Downdraft dengan Variasi Laju Aliran Oksigen Sebagai Agen Gasifikasi. Jurnal METTEK Volume 1 No 2 (2015) pp 1 - 8.

[4] Subroto., 2017. Kinerja Tungku Gasifikasi Downdraft Continue Bakar Sekam Padi. Jurnal Ilmiah Teknik Mesin Vol.18 No.1 Januari 2017: 24 -33 .

[5] Muhammad Ridwan., Indradjaja., Noviyanti Nugraha dan Irfan Taufik.,2018.Pengujian Kinerja Dan Modifikasi Reaktor Downdraft Gasifikasi Biomassa 100 kW. Jurnal Rekayasa Hijau No. 2 Vol 2 Juli 2018.

[6] Mustaqim Kamba., Romi Djafar., 2019. Kompor Biomassa Sistem Batch Menggunakan Bahan Bakar Sekam Padi. Jurnal Teknologi Pertanian Gorontalo (JTPG) Vol 4 No 1, Mei 2019.

[7] Riksa Prayogi Widyaprawira., R. Radi., Bambang Purwantana., 2019. Optimasi Gasifikasi Serbuk Tandan Kosong Kelapa Sawit Menggunakan Powder Gasifier Type Cyclone. Agritech, 39 (3) 2019, 258 - 269.

[8] Anjireddy Bhavanam, Sastry, R.C. 2011."Biomass Gasification Processes in Downdraft Fixed Bed Reactors: A Review, International Journal of Chemical Engineering and Applications, Vol. 2, No. 6, December 2011.

[9] Ajay Kumar, D.Jones David, A Hanna. 2009."Thermochemical Biomass Gasification: A Review of The Current Status of The Technology", Energies 2009, 2, 556-581: doi: 10.3390/en20300556.

[10] Ke Sun. 2014."Optimization of Biomassa Gasification Reaktor Using Aspen Plus", Faculty of Technology Kjolnes.
[11] Martínez, Juan Daniel \& Mahkamov, Khamid \& Andrade, Rubenildo V. \& Silva Lora, Electo E., 2012. "Syngas production in downdraft biomass gasifiers and its application using internal combustion engines," Renewable Energy, Elsevier, vol. 38(1), pages 1-9.

[12] Anil K Rajvanshi. 2014. "Biomass Gasification", Published as a Chapter (No.4) in book", Alternative Energy in Agriculture", Vol. II, Ed. D. Yogi Goswami, CRC Press, 1986, pgs. 83-102.

[13] Kementrian PPN/Bapennas, January 2020, Independent Assessment of Indonesia's Energy Infrastructure Sector.

[14] Roos Kities Andadari, Peter Mulder, Piet Rietveld, Energy poverty reduction by fuel switching. Impact evaluation of the LPG conversion program in Indonesia, Energy Policy, Volume 66, 2014, Pages 436-449, ISSN 0301-4215, https://doi.org/10.1016/j.enpol.2013.11.021.

[15] Herri Susanto, Pengembangan Teknologi Gasifikasi untuk Mendukung Kemandirian Energi dan Industri Kimia, 2018, ISBN. 978-602-662423-9.

[16] Fajri Vidian \& Rachmat Dwi Sampurno \& Ismail, 2018. "Cfd Simulation Of Sawdust Gasification On Open Top Thr oatless Downdraft Gasifier," Journal of Mechanical Engineering Research \& Developments (JMERD), Zibeline International Publishing, vol. 41(2), pages 106110, July.DOI: 10.26480/jmerd.02.2018.106.110.

[17] O Ismail, M Urbanus, H Murage, O Francis, Conversion of Rice Husks into an Energy Source through Gasification Technology, International Journal of Science and Research (IJRS) 5 (2016, 2319-70 